\title{
Towards Quality of Life in Construction Industry: Identification of employee turnover antecedents
}

\author{
Siti Hawa Mohd Kasmuri, Zulhabri Ismail, \\ Rumaizah Mohd Nordin, Norfashiha Hashim
}

Faculty of Architecture, Planning \& Surveying, Universiti Teknologi MARA, Malaysia

sithawa.mk@gmail.com, zulhabri@uitm.edu.my,drrumaizah@uitm.edu.my, norfashiha@uitm.edu.my

\begin{abstract}
Among the approaches to improve employee's life quality is through the balance of the work-life that connected to the high turnover. A systematic literature review offers an overview of the present state of research concerning the turnover antecedents in the construction industry. Based on Preferred Reporting Items for Systematic Reviews and Meta-analyses, three main themes of employee turnover antecedents are identified, namely: organisation, individual, and external antecedent. Two recommendations are made, including the development of life quality strategy and to conduct more employee turnover. Identification of adverse outcomes of turnover assists in improving employees life quality in the construction industry.
\end{abstract}

Keywords: SLR; Life Quality; Construction Industry

eISSN 2514-751X @ 2020 The Authors. Published for AMER ABRA cE-Bs by e-International Publishing House, Ltd., UK. This is an open access article under the CC BY-NC-ND license (http://creativecommons.org/licenses/bync-nd/4.0/). Peer-review under responsibility of AMER (Association of Malaysian Environment-Behaviour Researchers), ABRA (Association of Behavioural Researchers on Asians / Africans / Arabians) and cE-Bs (Centre for Environment-Behaviour Studies), Faculty of Architecture, Planning \& Surveying, Universiti Teknologi MARA, Malaysia.

DOI: https://doi.org/10.21834/ajebs.v5i17.376 


\subsection{Introduction}

Employee motivation to stay in the organisation depends on the motivation factors. The present study adopts the Maslow theory of need to frame the research flow among other motivation theories. This theory introduced by Abraham Maslow in 1943. Five hierarchies of need, including psychological, safety, belonging, esteem, and self-actualization, need to be achieved according to its level. The psychological and safety needs are fundamental to the human need, while others are considered as spiritual (Zhang, Liu, \& Wu, 2011). This theory that considers human needs as motivation to stay is relevant within this paper scope. Therefore, identification of quality of life can be relied whether Maslow aspects of human need are met.

\subsection{Quality of Work-life}

The current labour market issue has focused on the work-life balance. This situation has lead to a lack of life quality, which also the reason for demotivation. According to Rastogi, Rangnekar, \& Rastogi (2018) employee outcomes affected by the quality of work-life. Previous research has explored various factors of work-life. For example, the practice of human resource management (HRM), including inappropriate pay structure and chaotic work schedule that leads to stress Meharunisa (2019). Organisation practice of long working hours is the result of chaotic work schedule. This issue is seen as crucial across the industries affected the life quality in the long run (Adogbo, Ibrahim, \& Ibrahim, 2015; Gallego et al., 2015; Schmitz-Rixen \& Grundmann, 2020; Tlaiss, Martin, \& Hofaidhllaoui, 2017; Wadsworth, Llorens, \& Facer, 2018). Adverse employee outcomes can be seen through the reduction of employee satisfaction (Sang, Ison, \& Dainty, 2009), also the contribution to low work effort, poor performance, and turnover (Lim \& Ling, 2012). Previous research focuses on the life quality that leads to several recommendations, including part-time work arrangement, shift work options, and flexibility of working hours (Gallego et al., 2015; Schmitz-Rixen \& Grundmann, 2020; Tlaiss et al., 2017; Wadsworth et al., 2018). Thus, all related factors should be explored to improve life quality.

This aspect of the Malaysian construction context is defined clearly. Through the Construction Industry Development Board (CIDB), the context of life quality is seen from two perspectives. In the survey executed by the Construction Industry Development Board (CIDB). The work-life improvement has been the critical issue in the survey executed, in the year of 2015 that revealed $14 \%$ of response (102 respondents) require work-life improvement (Ipsos Loyalty, 2016). In another survey in 2017, the construction organisation is urged to improve the employment benefits package offered (Ipsos Loyalty, 2017). These findings show the importance of life quality through the role of the organisation management (Madihie \& Siman, 2016; Ofori, 2015; Worrall, Harris, Stewart, Thomas, \& McDermott, 2010) where employee turnover as among the adverse outcomes (Frufrek \& Pansanato, 2015; Leung, Chan, \& Olomolaiye, 2008; Sang et al., 2009). Besides, employee motivation affected by the nature of the industry. 
The followings are the example of demotivation factors; in terms of long working hours, lack of appreciation, poor leadership style, and poor career development (Moraes, Coelho De, \& Gladis, 2012). In the absence of a suitable approach to combat this circumstance, the possibility of repetition of such event is the high. Thus, lacking in retention strategy within the organisation found as the reason in high of turnover rate (Dierendonck, Lankester, Zmyslona, \& Rothweiler, 2016; Firth, Mellor, Moore, \& Loquet, 2004; Kshirsagar, 2016; Lim \& Ling, 2012; Pablo, Donate, \& Pen, 2016; Yaghi, 2016; X. Zhang, Ma, Xu, \& Xu, 2018). In the different perspective of the construction domain, critical success factors of the construction project are identified through the lack competent personnel (Mezher \& Tawil, 1998; Mohamed, Abuazoom, Hanafi, \& Ahmad, 2017; H. T. Nguyen \& Hadikusumo, 2017; L. D. Nguyen, Ogunlana, \& Lan, 2004; Pournader, Tabassi, \& Baloh, 2015; Tabassi \& Bakar, 2009). Through the systematic literature review approach, this paper seeks clarification on employee turnover antecedents.

\subsection{Methodology}

The Preferred Reporting Items for Systematic Reviews and Meta-analyses (PRISMA) that initiated in 1889, was employed to identify employee turnover articles in the construction industry.

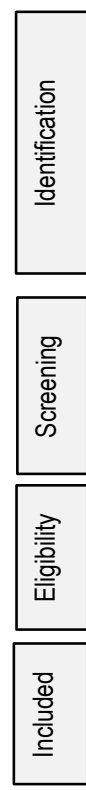

Records identified through database searching $(n=7,692)$

(Scopus $n=93$, EBSCHOhost $n=5,395$, ASCE $n=2,204$ )

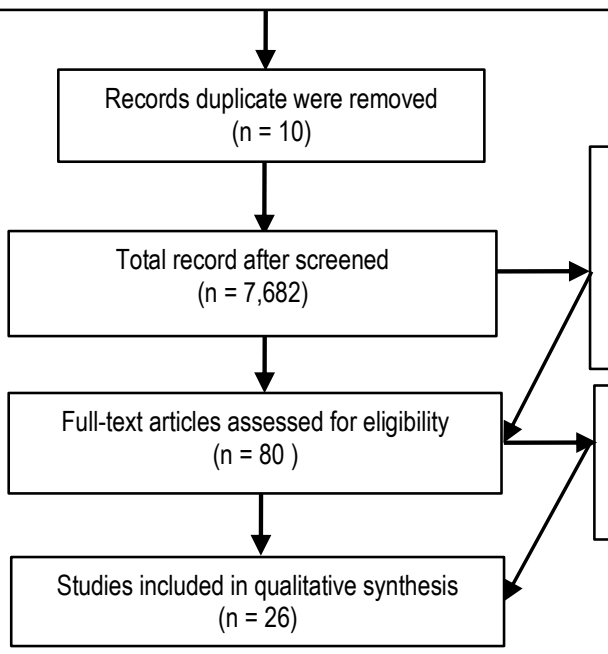

Records excluded $(n=7,602)$. Excluded due to : publication <below 1999, documents are article review, book review, book chapter and book, non-English article and other industries.

Full-text articles excluded with reasons $(n=54)$. Excluded due to not retention of employees studies.

Figure 1: The workflow diagram of the study 
The PRISMA offers a systematic approach of literature review by incorporating four stages process, namely: identification, screening, eligibility, and inclusion, offers a systematic approach of literature review (Moher, Liberati, Tetzlaff, \& Altman, 2009). This approach in other industries, such as medical, agricultural, and psychological, is often utilised. Based on predefined research questions, what are the antecedents of employee turnover, the relevant studies are identified (Shaffril, Krauss, \& Samsuddin, 2018). The predefined research question has guided the research flow as illustrated in Figure 1.

\subsection{Resources}

Three databases were utilised as platform sources in this study to identify relevant articles. Due to limited access to other databases (Web of Science), the databases utilised are including Scopus, EBSCOhost, and American Society of Civil Engineers (ASCE). One of the largest databases, the Scopus, is peer-reviewed literature from multiple disciplines that contain 39,467 journals. Meanwhile, the second database used in this paper has several coverages across disciplines, namely the EBSCOhost. The third database, ASCE, has 38 journals with a focus on the engineering and construction industry.

\subsection{Eligibility \& Exclusion Criteria}

In determining relevant articles, inclusion and exclusion criteria were developed (Moher et al., 2009). This paper has developed a timeline, document type, language, and subject terms as the criteria to met (see Figure 2). Articles published in the last decade (1999-2019) were selected to cater the recent findings. Articles and conference proceedings with empirical data were included. Articles written in English were selected. Subject criteria of employment and construction industry were embedded to synchronise with the study objective.

\subsection{Systematic Review Process}

The systematic review process as displayed in Figure 1, was conducted between February and March 2019. The identification of articles was identified from three databases. In this stage, utilised keywords were: (employee*), ("retention* OR stay OR leave OR turnover OR quit"), and ("construction industry") (see Figure 3). In order to identify relevant keywords, several references were used, including previous studies, thesaurus, any keyword similar, and any keywords related to employee turnover. Three review authors managed the articles' searching process in three databases. Ten duplicate articles were removed during the screening process in the second stage. 


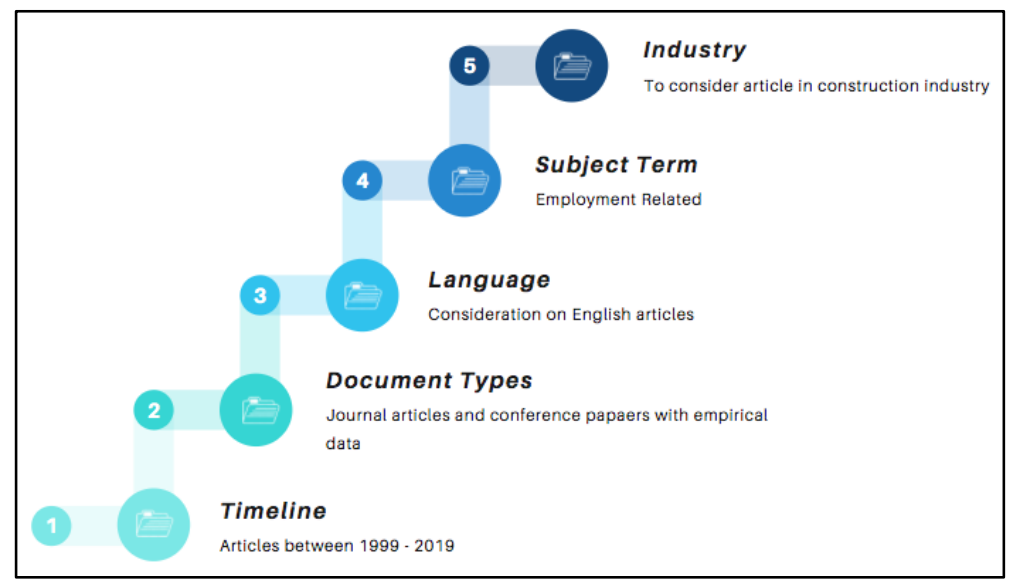

Figure 2: Inclusion Criteria

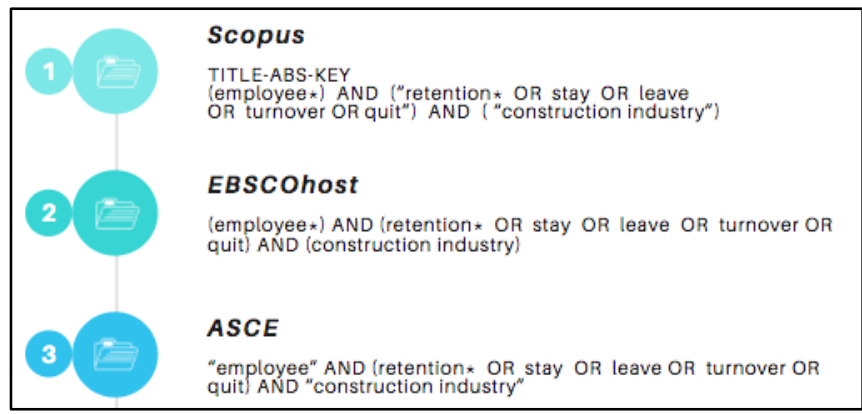

Figure 3: The Search String Process

\subsection{Data Abstraction and Analysis}

The process began with the abstract review. Articles were read in detail to determine whether the articles were in line with the study objective. The review process began with the authors required to review included articles from other authors who do the articles searching to reduce biasness (Liberati et al., 2012). The final findings of the reviews were concluded based on agreement from all authors. With the assistance of Computer Assisted Qualitative Data Analysis Software (COQDAS) the Atlas.Ti Version 8, identification of employee turnover determinants was performed by adopting the qualitative content analysis approach. The findings from the analysis can be summarised into the tabulated form within the social science context (Bronson, \& Davis, 2012). 


\subsection{Results}

\subsection{Sample of Reviewed Articles}

As illustrated in Figure 4 the articles involved three sample groups. Among the three samples, the employees' sample is the highest, with $70 \%$ of articles. The sample of employees, as involved three groups, namely general workers, construction professionals, and mixed employees. Meanwhile, construction projects and construction organisation were the other two sample groups. In terms of articles focus, four studies appeared to focus on gender in determining employee turnover issues. Even so, the reviewed article had to been varied to allow different dimensions of the findings.

The article reviewed included the publications derived from the past decade to allow for the timeline due to lack of publication in the research topic. The two highest publication year (the year 2015 and 2011) produced three articles, respectively. Followed by the publication of two articles in the year 2019, 2017, 2016, 2014 and 2013. There was a year where construction industry turnover was produced with one article (2018, 2012, 2010, 2008, 2006, and 2000). However, there were the years that no articles published in the research scope $(2005,2004,2003,2002,2001$, and 1999). Based on these findings, it can be concluded that the research topic in the construction industry shows an imbalance number of publications (see Figure 5). As shown in Figure 6, the most adopted research design in the samples was the quantitative approach with 19 articles. The adoption of other research designs, namely qualitative and mixed-method, shows a lack of articles with four and three articles, respectively.

\subsection{Employee Turnover Antecedents}

From the review exercise, the content analysis process concluded three themes with eight subthemes, including organisation (five), personal (three), and external theme that stood alone. The following section elaborates on the findings.

\section{- Organisation Antecedents}

This section involves an organisation antecedent that lies under the capacity of the management organisation. The following sections explain the findings.

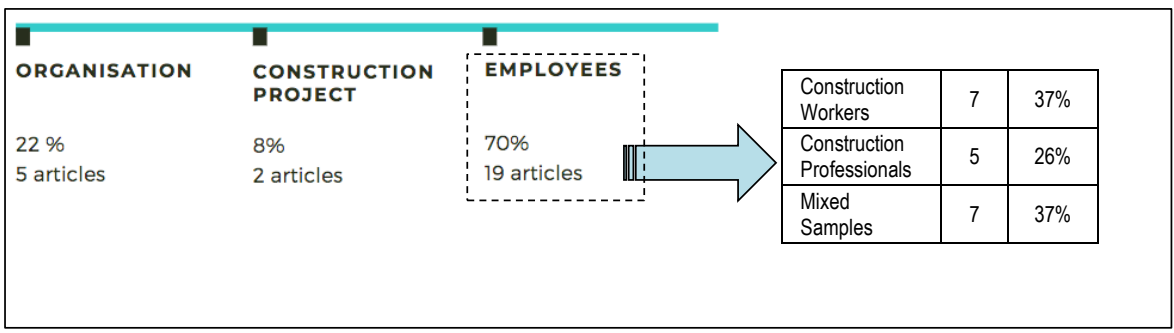

Figure 4: Sample of Articles 


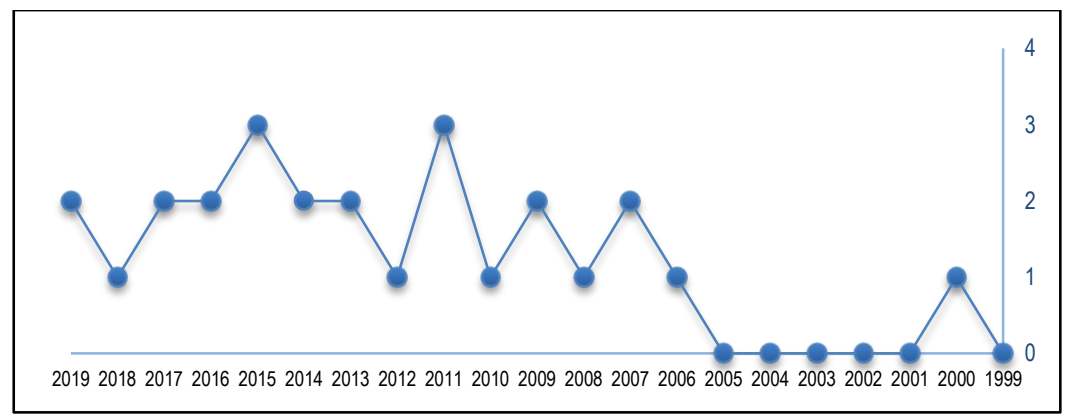

Figure 5: Year of Publication

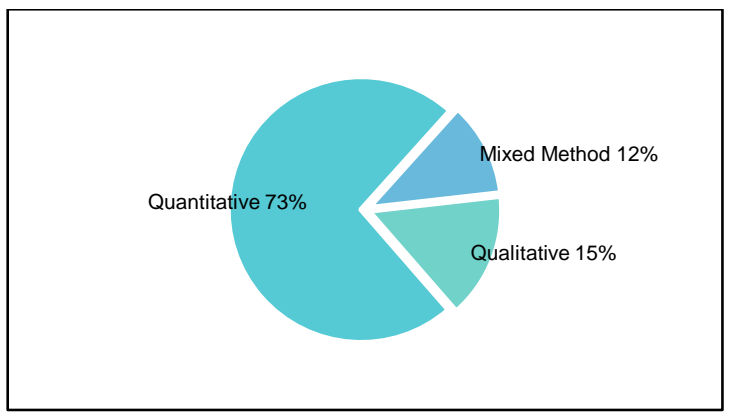

Figure 6: Research Design

\section{Organisation Management}

Organisation contributions to employee turnover are undeniable (see Table 1). Generally, resources management is required to explore the internal factors of an organisation that may affect turnover. Internal organisation factor is suggested to be investigated extensively (Shikweni et al., 2019) to avoid poor employee outcome such as the turnover (Sang et al., 2009). Besides, other previous authors have mentioned several outcomes, including commitment (Park, Christie, \& Sype, 2014) and job satisfaction (Du, Zhou, Liu, \& Picken, 2006). It has been explored that the role of a leader concerning turnover as crucial. With the relevant approaches, turnover reduction may be effectively discarded through the role of a leader (Jebens, Medbø, Knutsen, Mamen, \& Veierste, 2014; Rivas et al., 2011) while enhancement of the job satisfaction (Adogbo et al., 2015; Hee, \& Ling, 2011; Jebensa et al., 2014). Among the approaches that could be depended is by leading the way through a positive leadership style (Morello, Issa, \& Franz, 2018). The need for the task in the jobs might be different (Hee \& Ling, 2011; Morello et al., 2018), thus failing to fulfill their needs will result in leaving attitude (Meliá, \& Becerril, 2007). In another study of Yip and Rowlinson (2009), job security affects one emotionally, thus can lead to a lack of employee competency. 
As the job security factor may involve employee perception towards the organisation, the lack of job security will influence the commitment (Park et al., 2014).

Table 1: Organisation Antecedent

\begin{tabular}{ll}
\hline Authors & Remarks \\
\hline Shikweni, 2019 & internal organisation factor to be reviewed \\
Morello, 2018 & positive leadership style \\
Jebensa, 2015 & leader role in combatting the turnover possibility via job satisfaction role \\
Adogbo, 2015 & job satisfaction achieved through positive leader style \\
Park,2014 & outcome commitment that influence by management practice \\
Hee, 2011 & the role of leader in determining employee job satisfaction \\
Rivas, 2011 & superior responsibility to reduce tunover rate \\
Sang, 2009 & poor outcome of turnover through poor organisation practice \\
Yip, 2009 & job security leading to emotional feeling, competencies affected \\
Melia, 2007 & failed to fulfill task need due to lack of leader support \\
Du, 2006 & practice within the organsiation may lead to job satisfaction \\
\hline
\end{tabular}

\section{Compensation}

Table 2 shown compensation component. As part of human needs, employees are working for compensation. Pay, which refers to basic compensation of employment package, is vital for construction industry employee turnover (Loganathan \& Kalidindi, 2016; Rojas, 2013). Through the increment of the compensation package (Kim \& Philips, 2012; Park et al., 2014) employee perception towards organisation is improved (Park et al., 2014). This situation hinder turnover effect as a result of poor employee expectations towards compensation package (Rivas et al., 2011). However, another effect of compensation can be related to employee satisfaction in terms of monetary rewarding practice (Du et al., 2006). Another part that requires attention in the construction industry can be referred to equal compensation opportunities where, gender discrimination is the turning point in the male-dominated industry (Morello et al., 2018). The compensation package is challenged by a competitive labour market salary scale in which employees might be considered to opt for other employment through a better compensation offer (Loganathan \& Kalidindi, 2016; Rivas et al., 2011) or leave the profession permanently (Sang et al., 2009). In order to reduce this possibility, better compensation offer that competitive with the labour market may avoid the manipulation of payroll, and further can improve job satisfaction (Childs, Weidman, Pe, \& Christofferson, 2017; Rojas, 2013).

Table 2: Organisation Antecedent - Compensation

\begin{tabular}{ll}
\hline \multicolumn{1}{c}{ Authors } & Remarks \\
\hline Morello, 2018 & equal opportunities as the strategy to combat gender discrimination \\
Childs, 2017 & job satisfaction improvements \\
Loganathan, 2016 & to visible in the labour market through better compensation package \\
Rojas, 2016 & the importance of compensation package in turnover issue as job satisfaction factor \\
Park, 2014 & increment of salary assist in improving employee percpetion of organsiation practice \\
Kim, 2012 & increment of salary as the concern \\
Rivas, 2011 & improvement of employee expectation of the compensation package \\
Sang, 2009 & better offer of other position in labour market
\end{tabular}


Table 3: Organisation Antecedent - Training \& Development

\begin{tabular}{ll}
\hline Authors & Remarks \\
\hline Morello, 2018 & positive outcome through equal opportunities in career development \\
Rojas, 2016 & specific skills to perform job tasks \\
Hee, 2011 & job hooping as the result of poor career ladder \\
Keen, 2011 & professional licensing as a token to climb career ladder \\
Yip, 2009 & poor career development leads to job burnout \\
Du, 2006 & dissatisfaction due to lack of career development opportunities \\
\hline
\end{tabular}

\section{Hiring Process}

The hiring process is identified as one of the turnover reasons. (Childs et al. (2017) explored the personality profile assessment being utilised in the hiring process. In detail, several usages of this assessment, including personality characteristics to fit for the positions, identification of project team members that assist in satisfying clients' requirements in the project. The use of the assessment allows for a better working environment for the employees and the organisation. Even though low agreement on the contribution of the assessment to turnover is given, this approach should be explored extensively.

\section{Training and Development}

The appearance of the training and development component in the turnover factors has been investigated as shown in Table 3. In order to stay competitive in the organisation, the employee should get specific skills that required to fulfill the task's requirement (Rojas, 2013). Besides, the positive outcome of the employee who is trained can be seen through valuable skills in terms of technical and personal management skills.

Employees tend to stay if they feel that they have opportunities for career development. It is better to consider career progression opportunities, or employees may end up feeling burnout (Yip, \& Rowlinson, 2009) and dissatisfied (Du et al., 2006). However, several aspects should be considered. Morello et al. (2018), point that equal opportunities on career advancement allow for positive perception among employee towards the organisations by the feeling of fair treatment. Contradictedly, the employee who received no opportunities in these aspects may opt for other alternatives, such as job hooping (Hee \& Ling, 2011). In searching for career advancement opportunities, the employee should consider getting certified from the professional bodies as the token for the career ladder (Keen, 2011).

\section{Employee Engagement}

Working Hours. The construction industry practice in long working hours points to the issue of work-life imbalance. Hence, Rivas et al., (2011) suggested a better work system since this aspect affects employee's duration of stay in the organisation. Another issue related to work-life balance is the concern for construction employees. Despite variance in the sample, the issue of work-life balance is an essential factor in determining their retention in 
the organisation. For instance, women construction professionals required improvement in working hours where the focus to be given equally on the family (Malone, Issa, \& Asce, 2008;

Table 4: Organisation Antecedent - Employee Engagement (Working Hours)

\begin{tabular}{ll}
\hline Authors & Remarks \\
\hline Morello, 2018 & improvement of working hours \\
Loganathan, 2016 & work-life issue affect all employees reagrdless of gender \\
Malone, 2012 & improvement of working hours \\
Rivas, 2011 & better work system in assisting the issue of worklife imbalance \\
Sang, 2009 & work-life balance as the source of job satisfaction \\
Lingard, 2007 & alternative working hours and compressed work-week as the \\
& suggestions to cater the issue \\
\hline
\end{tabular}

Morello et al., 2018). Besides, the issue of the imbalance of work-life gets attention from general employees regardless of gender (Loganathan, \& Kalidindi, 2016). It can be concluded that the issue of work-life imbalance gets great attention in construction settings. As a result of work-life imbalance, the employee may show a negative outcome through job satisfaction role (Sang et al., 2009). Lingard et al., (2007) prescribed attaining a balance between the demand for work and life which, gained positive feedback from the sample, can be seen from alternative working hours to meet demand in work and life. (Lingard et al., 2007) proposed several options of recommendations including alternative working hours and compressed work-week. Table 4 shows working hours components.

Job-Related. Table 5 displays job-related details. One of the job-related factors that linked to turnover could be the workload. Employee loyalty can be from a reasonable workload distribution (Zhu, Zeng, Li, Zhu, \& Zhang, 2017). Through an exciting job designed to reduce specific preferences that involve employee health issues such as exposure to mechanical settings (Jebens et al., 2014) and proper coordination of work to enhance motivation (Rojas, 2013) development of exciting job design strategy can succeed. Another aspect to consider is the reasonable workload that can reduce emotional exhaustion through efficient coordination (Yip, \& Rowlinson, 2009). Another part of the job-related turnover to consider is involvement in the decision-making process. According to (Park et al., 2014) the situation when the employee gets involved in the decision making could assist in a better working system where subordinates' understanding is improved. In this situation, the likeliness to leave is reduced. This notion supported by Hee \& Ling (2011) who determine the level of employee satisfaction is improved.

Table 5: Organisation Antecedent - Employee Engagement (Job Related)

\begin{tabular}{ll}
\hline Authors & Remarks \\
\hline Rojas, 2016 & motivation improvemenet through the proper cordination of work \\
Kim, 2012 & changes of team size \\
Park, 2014 & involvement in decision-making process \\
Yip, 2007 & job design strategy to combat emotional exhaustion due to heavy workload \\
Hee, 2011 & satisfaction met in decision-making involvement \\
Zhu, 2017 & reasonable workload distribution
\end{tabular}


Jebensa, 2015 job performance affected by health issue

Another related job factor is team size. (Kim \& Philips, 2012) points out that in the situation where team members are reduced, a massive turnover will follow. In this circumstance, employee concerns are shown on the lack of job security even though the different actual situation has opted. However, some employees might leave in advance as the solution to their concerns.

Work Environment. Another employee engagement element is the work environment factor which can be seen as shown in Table 6 . The contribution of the work environment to turnover can be seen in the lack of facilities provided by the organisation (Loganathan, \& Kalidindi, 2016). Furthermore, the concern focuses on employee living quarters in the construction site that need to be equipped with proper housing facilities, complete with a clean area for living, sanitation, food, and medical services. However, the work environment factor has not to influence older employees but to the younger samples (Jebens et al., 2014). On top of that, employees concern the distance between the workplace and their home (Kim, \& Philips, 2012). Furthermore, Kim \& Philips (2012) asserted that although workplace distance that causes employees to commute daily may reduce termination issues, turnover as adverse effect remains. Despite the link of the work environment and turnover explained earlier, employee motivation (Rojas, 2013) and job satisfaction (Du et al., 2006) were found to be link closely rather than the turnover as the adverse effect.

\section{- Individual Antecedents}

This section involves an individual factor of turnover i.e., attitude and behavior.

\begin{tabular}{ll}
\multicolumn{2}{l}{ Table 6: Organisation Antecedent - Employee Engagement (Work Environment) } \\
\hline Authors & Remarks \\
\hline Loganathan, 2016 & lack of facilities provided \\
Rojas, 2016 & working environment as factor in employee motivation \\
Jebensa, 2015 & better working environemnt is essential to younger employees \\
Kim, 2012 & distance to workplace \\
Du, 2006 & working environment as factor in employee satisfaction \\
\hline
\end{tabular}

Table 7: Individual Antecedent - Demographic

\begin{tabular}{ll}
\hline Authors & Remarks \\
\hline Du, 2006 & not linked to turnover \\
Morello, 2018 & $\begin{array}{l}\text { women employees in younger age and older age possibility to leave due to } \\
\text { lifestyle and industry nature. Married women have difficulty to balance } \\
\text { wbetween work and life }\end{array}$ \\
Kim, 2012 & $\begin{array}{l}\text { younger employee high possibility to leave as compared to older } \\
\text { counterparts }\end{array}$ \\
Rivas, 2011 & short-term employment contract \\
Jones, 2010 & emploment in the industry based on project duration \\
Park, 2014 & profile of employees on total number of previous employment \\
\hline
\end{tabular}




\section{Demographic}

Table 7 presents demographic information. Demographic involves a variety of elements, such as gender, personal status, age, years of service, education level, position, and organisation types (union/non-union). The demographic attributes have changed within these two decades. In the first decade of articles publication, this factor was verified as not connected to turnover (Du et al., 2006). However, this notion was later opposed to some demographic factors that are closely related to turnover determinants. For instance Morello et al. (2018) determine age that links to the turnover, which women in the construction industry who in the age group of 18-24 and over 65 years old have shown likeliness to leave due to difficulties to cope with work and life with the nature of the industry is the reason.

Contradictly, (Kim \& Philips, 2012) argued that older employees are less involved in the turnover or resignation as compared to younger groups. The differences can rely on the reason of gender as the focus. Anne et al. (2018) explore women while the latter is generalized regardless of gender. In another demographic element, the position held by the employees. Kim \& Philips (2012) show the need for experience to perform works in the technical sector of the construction industry. In this situation, experienced employees have no issue performing well in works, while newcomers will likely have less experience that leads to their turnover. Three articles determined the year of service in the organisation. In (Rivas et al., 2011), employee turnover is due to the short-term of the employment contract that makes it compulsory for employees to automatically ended the contract. However, this notion is argued in which the contract can be continued based on other projects that the organisation may have. This situation is referred to as the mobile industry (Jones, Ross, \& Sertyesilisik, 2010) which employees may have different types of employment, and the regular practice is the short-term contract based that on project duration. From different perspectives, the numbers of worked organisation influence turnover intention due to skills developed in the previous different organisation (Park et al., 2014). Finally, the personal status that shows married women have difficulty to manage the demand for work and life (Morello et al., 2018).

\section{Commitment}

Data from several sources pointed out the influence of commitment and turnover within the construction industry settings, as illustrated in Table 8 . Three types of commitment, namely affective, continuance, and normative, are identified in the study by Meyer and Allen. Among these three types of commitment, normative or obligation to the organisation is found links to turnover (Koundinya, 2019). This finding can be related to the reason that commitment will engage employees and reduce turnover (Jun-Cheng, Quan, Yi, \& Xie, 2015). The lack of responsibility towards the company will reduce their engagement then leads to the turnover. Apart from the direct effect on turnover, commitment also affected the organisational practice (i.e., termination practice, types of organisations, and compensation), as well as the individual ability (Park et al., 2014). 
Table 8: Individual Antecedent - Commitment

\begin{tabular}{ll}
\hline Authors & Remarks \\
\hline Park, 2014 & $\begin{array}{l}\text { several outcomes related to commitment including the effect to } \\
\text { organisation and the employee }\end{array}$ \\
Koundinya, 2019 & $\begin{array}{l}\text { not declive commitment links to turnover, while the other two types are } \\
\text { committed employee engaged with the work and has low turnover }\end{array}$ \\
Zhang, 2015 & com
\end{tabular}

Table 9: Individual Antecedent - Communication Skills

\begin{tabular}{ll}
\hline Authors & Remarks \\
\hline Du, 2006 & the role of communication in job satisfaction \\
Zhu, 2017 & different usage of communication based on occupational groups \\
\hline
\end{tabular}

\section{Communication Skills}

The role of communication, as shown in Table 9, has been cited as a turnover factor. The findings concluded that communication could be treated differently among different occupational groups within the construction domain. In Zhu et al. (2017) who explore the construction workers utilise communication to personal interest (i.e., organisation HRM practices), which may affect their loyalty in the long run. Communication has been confirmed to correlate with job satisfaction, which contributes to turnover intention negatively amidst a sample of managerial and technical staff (Du et al., 2006). Generally, the outcome is similar, but the angle of usage differs depending on occupational thinking due to variances in education level.

\section{- External Antecedents}

Other antecedents that cannot be themed into the organisation and individual antecedents are grouped into the external antecedent. Recent studies have reported that external factors contribute to turnover issues through the labour market and current related legislations that formulate competitive organisation policy (Shikweni et al., 2019). The organisation is wellprepared to implement the policy which able to improve employer branding (Adogbo et al., 2015). These approaches may encounter a better job offer in the labour market (Jones et al., 2010). For the project-based element, the construction organisations are advised to take the initiative to explore the environment of project location in various aspects including the economic conditions, social security, medical services, language barrier (Oswald, Sherratt, \& Smith, 2015; Yang, Li, Zhu, Li, \& Wu, 2017). Finally, the role of the organisation to cater to women issues in the industry where the role of networking seems helpful to make them remain in the industry (Morello et al., 2018). The summary of external factor displays at Table 10. 
Table 10: Findings of External Antecedents

\begin{tabular}{ll}
\hline Author & Remarks \\
\hline Shikweni, 2019 & Consideration of the current labour market conditions and related regulatory \\
Adogbo, 2015 & Improvement of employer branding by considering updated requirements \\
Jones, 2010 & compete with other organiiation in labour market \\
Oswald, 2015 & exploration of the construction site conditions \\
Morello, 2018 & networking as the support to retain women employees \\
\hline
\end{tabular}

\subsection{Discussion}

This study adopts a systematic review of employee turnover antecedents in the construction industry. A total of 26 related articles were collected from three databases. The results showed that employee turnover study has less priority in the construction domain.

As mentioned earlier, human motivation requires concern in all need aspect. Thus, through the identification of turnover antecedent, the improvement in the quality of work-life can be achieved while avoiding adverse outcomes (Rastogi et al., 2018) and increase HRM practices (Meharunisa, 2019). From the analysis, it can be conceptualized that the work-life quality can be achieved by maintaining the positive employee outcome, as shown in Figure 7 below. Based on the analysis, three themes and nine sub-themes had emerged. Thus, the basis to develop life quality strategy can be based on three themes of turnover antecedents, identified through the systematic reviews. The three main turnover determinants are the organisation, individual, and external determinants, whereas management, compensation, training, and development, employee engagement, demographic, commitment, and communication are the sub-themes. It was found that the organisation is a crucial determinant as compared to the other two other themes.

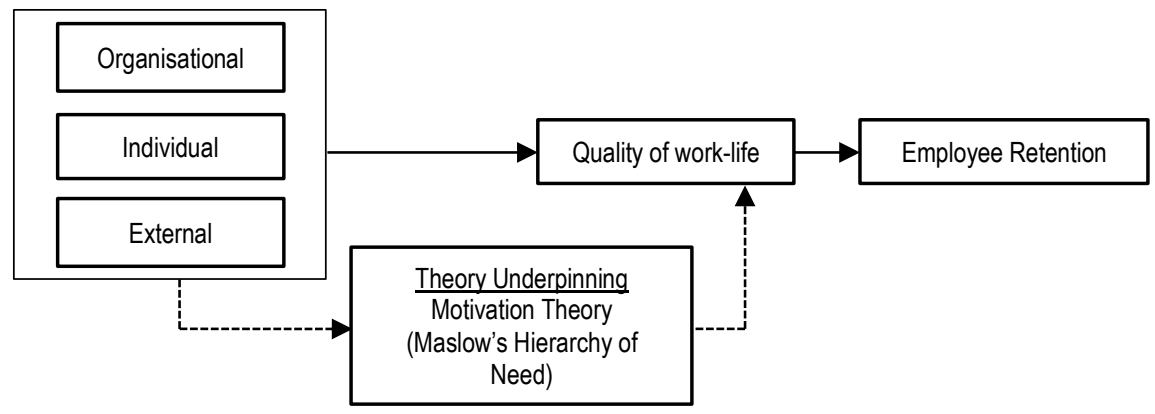

Figure 7: Conceptual Framework

It was found that several factors could influence employee turnover in the construction industry. The fundamental employment element should be considered to develop effective organisation management procedures since the organisation is the body that creates employment opportunities in the labour market. The procedure, policy, and practice within an 
organisation that demands high consideration is related to the supervisor/leader attitude, job security, and human resource management practice. For the supervisor attribute, the management should execute a routine evaluation to improve their competencies in line with the needs of their subordinates. In ensuring job security, problems faced by employees should be addressed. Next, the human resource management factor includes compensation, hiring process, training, and career development, as well as employee engagement. The concept of compensation is related to employee motivation, which is a fundamental fraction of life. Failure to provide reasonable compensation is viewed as a failure of a company in meeting its needs. In the hiring process, however, the proposed steps, such as employment advertisement sources and profile assessment, require further evaluation throughout employment years. A prospective candidate who uses tactics to get the job may face problems during the employment years. In light of training and career development, employees in the construction industry, regardless of occupational groups, found that training requirements (i.e., basic training and professional license) are essential to advance their careers. Next, if employee engagement factors, including working hours and work environment, are taken into account by the management organisation, turnover may be hindered.

Individual antecedents are also a contributing factor to turnover. The findings revealed that demographic factors, such as age, position, year of services, employee type, personal status, and gender, generated inequality in practice within the construction industry due to claims of the industry as being male-dominated, irregular working hours, and workplace outside / far from home / international assignment. This finding suggests the formulation of viable practice/strategy that can support all groups mentioned to retain valuable employees. It also highlighted commitment issues and communication skills due to the lack of individual skills and other related factors, such as lack of attention from employers to engage employees. Retention in the individual perspective should lie in an individual dimension, which effort to improve their ability would be essential.

Finally, external factors involve attributes that are beyond the control of individuals and the organisation, such as location of work, language barrier, regulatory, labour market demand, alternative job, and networking. Although these factors are beyond control, specific strategies that cover these factors can still be applied to devise effective retention strategies.

\subsection{Conclusion \& Recommendation}

The systematic review highlights important turnover antecedents in the construction domain. Two scopes are recommended to be undertaken in future studies. Towards improving employee work-life balance in the construction industry, the review suggests new directions for future research in employee turnover as part of the life quality strategy. Identification of employee turnover antecedents could assist in the development of a life quality strategy. However, due to the limitation of this topic in construction industry research, current findings should be the platform to undertake more similar research topics in the future. Several 
recommendations are made. Due to the limitation of articles based on recent data, future research may undertake more turnover-related research in the construction industry. Besides, future research may involve more professional employees as a sample, as they are important personnel to achieve the success of the constructon projects. Furthermore, lastly, in terms of research design which future research should explore qualitative or mixe-method approaches as the step to get more valuable findings where quantitative might left behind.

\section{Acknowledgement}

The authors would like to thank the funding body of this research; Bestari Perdana Research Grant from Universiti Teknologi MARA, Malaysia. (File No: 600-IRMI/PERDANA 5/3 BESTARI (071/2018).

\section{References}

Adogbo, K. J., Ibrahim, A. D., \& Ibrahim, Y. M. (2015). Development of a Framework for Attracting and Retaining Women in Construction Practice. Journal of Construction in Developing Countries, 20(1), 99-115.

Anne, M., A., I. R. R., \& Bryan, F. (2018). Exploratory Study of Recruitment and Retention of Women in the Construction Industry. Journal of Professional Issues in Engineering Education and Practice, 144(2), 4018001. https://doi.org/10.1061/(ASCE)El.1943-5541.0000359

Bronson, D. E., \& Davis, T. S. (2012). Finding and Evaluating Evidence. Systematic Reviews and Evidence-Based Practice. (T. Tripodi, Ed.). New York: Oxford University Press.

Childs, B. R., Weidman, J. E., Pe, C. B. F., \& Christofferson, J. P. (2017). Use of Personality Profile Assessments in the U.S. Commercial Construction Industry. International Journal of Construction Education and Research, 00(00), 1-17. https://doi.org/10.1080/15578771.2016.1246493

Dierendonck, D. Van, Lankester, A., Zmyslona, M., \& Rothweiler, H. (2016). Linking HRM Practices and Institutional Setting to Collective Turnover : An Empirical Exploration. Adm. Sci., 6(18). https://doi.org/10.3390/admsci6040018

Du, J. J., Zhou, J. I. E., Liu, C., \& Picken, D. (2006). Exploring Turnover Intention Of Construction Managers In China. Journal of Construction Research, 7(2006), 191-205.

Firth, L., Mellor, D. J., Moore, K. A., \& Loquet, C. (2004). How can managers reduce employee intention to quit? Journal of Managerial Psychology, 19(2), 170-187. https://doi.org/10.1108/02683940410526127

Frufrek, G. L., \& Pansanato, L. T. E. (2015). Employee turnover: An analysis of Brazilian software development professionals. 8th IADIS International Conference on Information Systems, IS 2015, (January 2015), 145-152. Retrieved from https://www.scopus.com/inward/record. uri?eid=2-s2.0 84944089117\&partnerlD=40\&md5=2c680b47ada853935daf620d9e2a3552

Gallego, G., Dew, A., Bulkeley, K., Veitch, C., Lincoln, M., Bundy, A., \& Brentnall, J. (2015). Factors affecting retention of allied health professionals working with people with disability in rural New South Wales, Australia: discrete choice experiment questionnaire development. Human Resource for Health, 13(22), 1-12. 
https://doi.org/10.1186/s12960-015-0013-7

Hee, C. H. S., \& Ling, F. Y. Y. (2011). Strategies for reducing employee turnover and increasing retention rates of quantity surveyors. Construction Management and Economics, 29(10), 1059-1072. https://doi.org/10.1080/01446193.2011.637569

Ipsos Loyalty. (2016). Final Report Public Perception. Retrieved from https://www.google.com/url?sa=t\&rct=j\&q=\&esrc=s\&source=web\&cd=1\&ved=0ahUKEwiY0d6RwPvVAhVBqY8KH R8WAEAQFggnMAA\&url=http $\% 3 \mathrm{~A} \% 2 \mathrm{~F} \% 2 \mathrm{Fwww}$.cidb.gov.my $\% 2$ Fimages $\% 2 F$ content $\% 2 \mathrm{Fpdf} \% 2 \mathrm{Fstatistik} \% 2 \mathrm{FPU}$ BLIC-PERCEPTION-2015.pdf\&usg=AFQjCNFuUBnFQD3YLs3VWVeOedboFaTP8g Ipsos Loyalty. (2017). Public Perception of CIDB : From the general public perspective.

Jebens, E., Medbø, J. I., Knutsen, O., Mamen, A., \& Veierste, K. B. (2014). Association between perceived present working conditions and demands versus attitude to early retirement among construction workers. Work, 48(2), 217228. https://doi.org/10.3233/WOR-141863

Jones, S. M., Ross, A., \& Sertyesilisik, B. (2010). Testing the unfolding model of voluntary turnover on construction professionals. Construction Management and Economics, 28(3), 271-285. https://doi.org/10.1080/01446191003587737

Jun-Cheng, Z., Quan, L. W., Yi, Z. Z., \& Xie, J. (2015). Organizational commitment, work engagement, personsupervisor fit, and turnover intention: A total effect moderation model. Social Behavior and Personality, 43(10), 16571666. https://doi.org/10.2224/sbp.2015.43.10.1657

Keen, J. (2011). The Retention of Women in the Architectural Engineering Workforce. ASCE.

Kim, J., \& Philips, P. (2012). Determinants of Quits and Dismissals on a Long-Lasting Unionized Industrial Construction Project, 138(May), 661-669. https://doi.org/10.1061/(ASCE)C0.1943-7862.0000451.

Koundinya, A. (2019). Organisational Commitment \& Turnover Intention among Employees of Construction Industry. International Journal of Mechanical Engineering and Technology (IJMET).

Kshirsagar, V. S. (2016). A Study of HRM Practices among Small and Medium Manufacturing Sector Units: A Comparative Study. SIES Journal of Management, 12(1), 51-57. Retrieved from http://search.ebscohost.com/login.aspx?direct=true\&db=buh\&AN=117314084\&site=ehost-live

Leung, M., Chan, Y., \& Olomolaiye, P. (2008). Impact of Stress on the Performance of Construction Project Managers, (August), 644-653.

Liberati, A., Altman, D. G., Tetzlaff, J., Mulrow, C., Gøtzsche, P. C., loannidis, J. P. A., ... Moher, D. (2012). The Prisma Statement For Reporting Systematic Reviews And Meta-Analyses Of Studies That Evaluate Healthcare Interventions: Explanation And Elaboration. Rev Esp Nutr Comunitaria, 18(1), 57-58. https://doi.org/10.1136/bmj.b2700

Lim, L. J. W., \& Ling, F. Y. Y. (2012). Human resource practices of contractors that lead to job satisfaction of professional staff. https://doi.org/10.1108/09699981211192599

Lingard, H., Ph, D., Brown, K., Ph, D., Bradley, L., Ph, D., ... Ph, D. (2007). Improving Employees ' Work-Life Balance in the Construction Industry: Project Alliance Case Study, (October), 807-816.

Loganathan, S., \& Kalidindi, S. N. (2016). Absenteeism and Turnover of Migrant Construction Workers in Indian 
Projects-A Survey-Based Study. Construction Research Congress 2016, 1793-1802.

Madihie, A., \& Siman, R. A. (2016). Issues Occurrence of Career Success Among Female Engineers. Journal of Cognitive Sciences and Human Development, 2(1), 24-36.

Malone, E. K., Issa, R. R. A., \& Asce, F. (2008). Predictive Models for Work-Life Balance and Organizational Commitment of Women in the U . S . Construction Industry. https://doi.org/10.1061/(ASCE)C0.1943-7862.0000809.

Meharunisa, S. (2019). Work-life balance and job stress among female faculties in India's higher education institutions. International Journal of Recent Technology and Engineering, 8(2S11), 846-852. https://doi.org/10.35940/ijte.B1139.0982S1119

Meliá, J. L., \& Becerril, M. (2007). Psychosocial sources of stress and burnout in the construction sector : A structural equation model, 19, 679-686.

Mezher, T. M., \& Tawil, W. (1998). Causes of delays in the construction industry in Lebanon. Engineering, Construction and Architechtural Management, 5(3), 252-260.

Mohamed, M., Abuazoom, I., Hanafi, H. Bin, \& Ahmad, Z. Bin. (2017). Influence of HRM Practices on Project Performance: Conceptual Framework. International Journal of Academic Research in Business and Social Sciences, 7(3), 47-54. https://doi.org/10.6007//JARBSS/v7-i3/2691

Moher, D., Liberati, A., Tetzlaff, J., \& Altman, D. G. (2009). Preferred reporting items for systematic reviews and meta-analyses: The PRISMA statement. Journal of Chinese Integrative Medicine, 6(7), 1-7. https://doi.org/10.3736/jcim20090918

Moraes, P. V., Coelho De, C. G., \& Gladis, C. (2012). Maslow's theory of motivation - Hierarchy of needs: Results from construction operational workers in São Paulo city, Brazil. Applied Mechanics and Materials, 174-177, 23392342. https://doi.org/10.4028/www.scientific.net/AMM.174-177.2339

Morello, A., Issa, R. R. A., \& Franz, B. (2018). Exploratory Study of Recruitment and Retention of Women in the Construction Industry. Journal of Professional Issues in Engineering Education and Practice, 144(2), 04018001. https://doi.org/10.1061/(asce)ei.1943-5541.0000359

Nguyen, H. T., \& Hadikusumo, B. (2017). Impacts of human resource development on engineering , procurement, and construction. Built Environment Project and Asset Management, 7(1), 73-85. https://doi.org/10.1108/BEPAM04-2016-0010

Nguyen, L. D., Ogunlana, S. O., \& Lan, D. T. X. (2004). A study on project success factors in large construction projects in Vietnam. Engineering, Construction and Architectural Management, 11(6), 404-413. https://doi.org/10.1108/09699980410570166

Ofori, G. (2015). Nature of the Construction Industry , Its Needs and Its Development : A Review of Four Decades of Research, 20(2), 115-135.

Oswald, D., Sherratt, F., \& Smith, S. (2015). Doing The 'Funky Chicken ' To Communicate On Multinational Doing The ' Funky Chicken ' To Communicate On Multinational Projects; The expansion of the European Union has led to an influx of foreign workers into the, (September).

Pablo, D., Donate, M. J., \& Pen, I. (2016). HRM practices for human and social capital development : effects on innovation capabilities. The International Journal of Human Resource Management, 2016, 27(9), 928-953. 
https://doi.org/http://dx.doi.org/10.1080/09585192.2015.1047393 HRM

Park, H. Y., Christie, R. L., \& Sype, G. E. (2014). Organizational Commitment and Turnover Intention in Union and Non- Union Firms. SAGE Open, January-Ma, 1-11. https://doi.org/10.1177/2158244013518928

Pournader, M., Tabassi, A. A., \& Baloh, P. (2015). A three-step design science approach to develop a novel human resource-planning framework in projects: The cases of construction projects in USA, Europe, and Iran. International Journal of Project Management, 33(2), 419-434. https://doi.org/10.1016/j.jproman.2014.06.009

Rastogi, M., Rangnekar, S., \& Rastogi, R. (2018). Psychometric evaluation of need-based quality of work life scale in an Indian sample. Industrial and Commercial Training, 50(1), 10-19. https://doi.org/10.1108/ICT-06-2017-0041

Rivas, R. A., Borcherding, J. D., Ph, D., Asce, M., González, V., Ph, D., ... Asce, A. M. (2011). Analysis of Factors Influencing Productivity Using Craftsmen Questionnaires: Case Study in a Chilean Construction Company, 137(April), 312-320. https://doi.org/10.1061/(ASCE)C0.1943-7862.0000274.

Rojas, E. M. (2013). Identifying, Recruiting , and Retaining Quality Field Supervisors and Project Managers in the Electrical Construction Industry, 29(October), 424-434. https://doi.org/10.1061/(ASCE)ME.1943-5479.0000172.

Sang, K. J. C., Ison, S. G., \& Dainty, A. R. J. (2009). The job satisfaction of UK architects and relationships with work-life balance and turnover intentions. Engineering, Construction and Architectural Management, 16(3), 288300. https://doi.org/10.1108/09699980910951681

Schmitz-Rixen, T., \& Grundmann, R. T. (2020). Surgical leadership within rapidly changing working conditions in Germany. Innovative Surgical Sciences, 4(2), 51-57. https://doi.org/10.1515/iss-2019-0002

Shaffril, H. A. M., Krauss, S. E., \& Samsuddin, S. F. (2018). A systematic review on Asian's farmers' adaptation practices towards climate change. Science of the Total Environment, 644, 683-695. https://doi.org/10.1016/j.scitotenv.2018.06.349

Shikweni, S., Schurink, W., Wyk, R. Van, Africa, S., Wyk, R. Van, Schurink, W., \& Wyk, V. (2019). Talent management in the South African construction industry. SA Journal of Human Resource Management, 17(0), 1-12.

Tabassi, A. A., \& Bakar, A. H. A. (2009). Training, motivation, and performance : The case of human resource management in construction projects in Mashhad , Iran. International Journal of Project Management, 27(5), 471480. https://doi.org/10.1016/j.jproman.2008.08.002

Tlaiss, H. A., Martin, P., \& Hofaidhllaoui, M. (2017). Talent retention : evidence from a multinational firm in France. https://doi.org/10.1108/ER-07-2016-0130

Wadsworth, L., Llorens, J. L., \& Facer, R. L. (2018). Do workplace flexibilities influence employment stability? An analysis of alternative work schedules, turnover intent and gender in local government. International Journal of Organization Theory and Behavior, 21(4), 258-274. https://doi.org/10.1108/IJOTB-07-2018-0077

Worrall, L., Harris, K., Stewart, R., Thomas, A., \& McDermott, P. (2010). Barriers to women in the UK construction industry. Engineering, Construction and Architectural Management, 17(3), 268-281. https://doi.org/10.1108/09699981011038060

Yaghi, A. (2016). Is it the human resource policy to blame ? Examining intention to quit among women. Gender in Management: An International Journal, 31(7), 479-495. https://doi.org/10.1108/GM-11-2015-0094

Yang, F., Li, X., Zhu, Y., Li, Y., \& Wu, C. (2017). Job burnout of construction project managers in China: A cross- 
sectional analysis. International Journal of Project Management, 35, 1272-1287. https://doi.org/http://dx.doi.org/10.1108/MRR-09-2015-0216

Yip, B., \& Rowlinson, S. (2009). Job Burnout among Construction Engineers Working within Consulting and Contracting Organizations. Journal of Management in Engineering, 25(3), 122-130. https://doi.org/10.1061/(ASCE)0742-597X(2009)25:3(122)

Zhang, L., Liu, X., \& Wu, Y. (2011). Research of construction enterprises' incentive strategies on the new generation of migrant workers with fuzzy preference relation models. International Conference on Management and Service Science, MASS 2011, 1-4. https://doi.org/10.1109//CMSS.2011.5998180

Zhang, X., Ma, L., Xu, B., \& Xu, F. (2018). How social media usage affects employees' job satisfaction and turnover intention: An empirical study in China. Information and Management, 56(November 2017). https://doi.org/10.1016/j.im.2018.12.004

Zhu, W., Zeng, R., Li, X., Zhu, Y., \& Zhang, Z. (2017). Managerial Drivers of Chinese Labour Loyalty in Intrnational Projects. Journal of Civil Engineering and Management, 23(8), 1109-1122. https://doi.org/10.3846/13923730.2017.1381644 